\title{
Effect of freeze-dried Carica papaya leaf juice on inflammatory cytokines production during dengue virus infection in AG129 mice
}

\author{
Nor Azrina Norahmad ${ }^{1 *+}$ (D) Mohd Ridzuan Mohd Abd Razak ${ }^{1+}$, Norazlan Mohmad Misnan ${ }^{1}$, Nur Hana Md Jelas ${ }^{1}$, \\ Umi Rubiah Sastu', Amirrudin Muhammad', Tiffiny Chau Dee Ho', Bazilah Jusoh', Nor Azlina Zolkifli', \\ Ravindran Thayan², Adiratna Mat Ripen ${ }^{3}$, Murizal Zainol ${ }^{1}$ and Ami Fazlin Syed Mohamed ${ }^{1}$
}

\begin{abstract}
Background: Carica papaya leaves have been used for traditional treatment of dengue fever and have been reported to exhibit an immunomodulatory activity by affecting the level of cytokine production in vitro and in vivo. Due to the lack of adequate in vivo evidence in dengue disease model, the present study was initiated to screen and identify the cytokines affected by freeze-dried C. papaya leaf juice (FCPLJ) treatment in AG129 mice infected with DEN-2 dengue virus.

Methods: The AG129 mice were fed orally with FCPLJ for 3 consecutive days after $24 \mathrm{~h}$ of dengue virus inoculation. Plasma cytokines were screened by using ProcartaPlex immunoassay. The gene expression in the liver was analyzed by using $\mathrm{RT}^{2}$ Profiler PCR Array.
\end{abstract}

Results: The results showed that FCPLJ treatment has increased the plasma CCL2/MCP-1 level during peak of viremia. Gene expression study has identified 8 inflammatory cytokine genes which were downregulated in the liver of infected AG129 mice treated with FCPLJ. The downregulated inflammatory cytokine genes were CCL6/MRP1, CCL8/MCP-2, CCL12/MCP-5, CCL17/TARC, IL1R1, IL1RN/IL1Ra, NAMPT/PBEF1 and PF4/CXCL4.

Conclusion: The findings indicated the possible immunomodulatory role of FCPLJ during dengue virus infection in AG129 mice.

Keywords: Carica papaya, AG129, Dengue, Cytokine, Gene expression, In vivo

\section{Background}

Dengue is rapid emerging mosquito-borne viral disease, affecting countries in tropical and subtropical regions around the world. Globally, it is estimated that there are 390 million dengue infection occur each year [1]. The virus is being transmitted through the bites of female Aedes mosquito infected with one of four dengue virus serotypes (DEN-1, DEN-2, DEN-3 and DEN-4). For a

\footnotetext{
* Correspondence: azrina@imr.gov.my

${ }^{\dagger}$ Nor Azrina Norahmad and Mohd Ridzuan Mohd Abd Razak contributed equally to this work.

${ }^{1}$ Herbal Medicine Research Center, Institute for Medical Research, Ministry of Health Malaysia, 50588 Kuala Lumpur, Malaysia

Full list of author information is available at the end of the article
}

healthy individual, the first symptom of the disease appears 3-7 days after being bitten by an infected mosquito. The symptoms ranged from mild to high fever, severe headache with muscle and joint pain. The dengue hemorrhagic fever is characterized by fever, hemorrhagic sign, thrombocytopenia and plasma leakage [2]. The pathogenesis of dengue infection involves host-specific immune responses, including immune cell activation, secretion of cytokines and chemokines, the production of inflammatory mediators, and autoimmunity [3]. For example, high level of proinflammatory cytokines such as TNF- $\alpha$, IL- 6 and IL-8 were observed during delayed viral clearance that results in endothelial activation and vascular leakage [4]. 
In the absence of antiviral drug to treat the disease, various alternative treatments are being explored including C. papaya leaf juice (CPLJ). Many scientists have investigated the possible use of this plant as supportive treatment for dengue patients. The beneficial effects of CPLJ and extracts in increasing the platelet level in rodents have been studied extensively [5-8]. For the past 10 years, a number of clinical trial and clinical case studies on the platelet increasing property of CPLJ or extracts in dengue patient have been reported [9-13].

The C. papaya leaf extract and juice were also studied for their antioxidant and immunomodulatory activities in vitro $[14,15]$ and in vivo $[6,16,17]$. The leaves extract has been shown to regulate certain cytokine production in activated human peripheral blood mononuclear cells (PBMCs) in vitro $[14,15,18]$. An in vivo study has shown that $C$. papaya leaf extract treatment reduced the inflammatory effect in paw oedema induced rats [6]. In addition, the CPLJ treatment has also reduced the TNF- $\alpha$ production, increased the phagocytic index and prevented the reduction of leucocyte count in cyclophosphamide-induced neutropenia rats [16]. Moreover, white blood cell count, bone marrow cell count, splenocyte count and peritoneal macrophages phagocytic activity were increased in healthy rats treated with CPLJ [17].

In the present study, we looked at the potential of freeze-dried C. papaya leaf juice (FCPLJ) as part of dengue treatment by investigating its effects on inflammatory cytokines in the plasma of dengue virus infected AG129 mice. In addition, we also analyzed the gene expression profiles of 84 mouse inflammatory cytokines \& receptors that would be affected by the FCPLJ treatment in the liver of dengue virus infected AG129 mice.

\section{Methods FCPL preparation}

Fresh and healthy green leaves of C. papaya were collected from the herbal garden of the Institute for Medical Research, Kuala Lumpur, Malaysia. The plant was identified by Ms. Tan Ai Lee, a botanist from Forest Research Institute Malaysia, Kepong, Malaysia (FRIM). A voucher specimen was deposited at the FRIM (Voucher No: 007/10). The leaves were cleaned thoroughly with veggie wash to remove any contaminant and rinsed with reverse osmosis water. The juice from the leaves was extracted by using a juicer and the remaining husk was pressed using a clean laboratory cloth. The juice was placed in containers and kept frozen at $-50{ }^{\circ} \mathrm{C}$ prior to freeze drying process (Virtis Advantage, SP Scientific, USA). The green powder was kept at $4{ }^{\circ} \mathrm{C}$ until further use. The powder was dissolved in distilled water prior to dosing.

\section{Analytical high performance liquid chromatography (HPLC) analysis}

The flavonoid compounds; nicotiflorin and rutin were purchased from Extrasynthese (Genay, France) whereas clitorin and manghaslin were isolated from C. papaya leaf extract and the structural elucidation were compared to previous publish data [19-21]. Analysis of HPLC was performed to monitor these flavonoid compounds in C. papaya leaf samples on a Waters 2695 HPLC system (Milford, USA) equipped with a Waters 996 photodiode array detector and a Waters 2695 separation module with empower 2.0 software. A Waters Symmetry C18 Column, $300 \AA \AA, 5 \mu \mathrm{m}, 3.9 \mathrm{~mm} \mathrm{X} 150$ $\mathrm{mm}$, (Milford, USA) was used as stationary phase and the mobile phase consisted of water containing $0.01 \%$ Trifluoroacetic acid (TFA) (Solvent A) and acetonitrile containing $0.01 \%$ TFA (Solvent B). The gradient solvent system of solvent A and solvent B as follows: $90 \%$ solvent $A$ until $5 \mathrm{~min}$, followed by $90-750 \%$ solvent A over $20 \mathrm{~min}$, then $75-5 \%$ A over $5 \mathrm{~min}$, then going back to $90 \%$ solvent A until $5 \mathrm{~min}$, and finally reconditioning the column with $90 \%$ solvent A isocratic for $5 \mathrm{~min}$. The flow rate for this analysis was maintain in $1.0 \mathrm{ml} / \mathrm{min}$ and the injection volume were $20 \mu \mathrm{l}$. The chromatogram was monitored using a wavelength range of $210-400 \mathrm{~nm}$.

\section{Propagation of viruses for inoculation}

The dengue virus propagation was prepared according to procedures described by McCormich et al., 2012 [22] with some modification. The New Guinea C, a DEN-2 strain, was propagated in C6/36 mosquito cells in Leibovitz's L-15 medium supplemented with $2 \%$ fetal bovine serum, $10 \%$ tryptose phosphate broth, $100 \mathrm{U} / \mathrm{ml}$ penicillin $\mathrm{G}$ and $100 \mu \mathrm{g} / \mathrm{ml}$ streptomycin at $28^{\circ} \mathrm{C}$. For quantification of virus, $4.5 \times 10^{5}$ cells/well of Vero cells were grown in each well of a 6-well plate containing $1.5 \mathrm{ml}$ Dulbecco's modified Eagle's medium (DMEM) for $24 \mathrm{~h}$ until confluent. Then, the media overlaying the monolayer was discarded and $100 \mu \mathrm{l}$ of cell supernatant containing virus suspension were allowed to adsorb for one hour. One $\mathrm{ml}$ of an overlay medium containing $1 \%$ agarose in 1X DMEM medium was added to cell monolayer and incubated for 7 days at $37^{\circ} \mathrm{C}$ in $5 \% \mathrm{CO}_{2}$ incubator. The uninfected cells were stained blue with $1 \%$ crystal violet in $20 \%$ ethanol leaving clear plaques of infected cells on the monolayer. The infectivity titre is expressed as the number of plaque forming units per $\mathrm{ml}(\mathrm{PFU} / \mathrm{ml})$.

\section{Experimental animal and dengue viruses inoculation}

Four weeks old, male AG129 mice (129/Sv mice deficient in both alpha/beta and gamma interferon receptors) were procured from Marshall BioResources, United Kingdom. Upon arrival, all mice were quarantined for 2 weeks and acclimatized for 1 week under a well-ventilated 
environment in Non-clinical Research Facility, Institute for Medical Research, Kuala Lumpur, Malaysia. The mice were housed in individual ventilated cages supplied with reverse osmosis drinking water and mouse pellet ad libitum.

The mice were divided into two experiments; plasma cytokine screening and gene expression analysis. For each experiment, the mice were divided into 3 groups of five: mock infected (uninfected; $\mathrm{N}=5$ ); infected $(\mathrm{N}=5$ ) and infected with FCPLJ treatment $(\mathrm{N}=5)$. The mice were inoculated with 2 X $10^{6}$ PFU DEN-2, New Guinea C strain, in $0.2 \mathrm{ml}$ volume intraperitoneally for infected group and $0.2 \mathrm{ml}$ plain media for mock infected group.

After dengue virus inoculation through intraperitoneal route, the body weight of the mice were recorded daily. The sign of illness was visually monitored twice a day during the experiment. The sign of illness was scored based on 1 to 5 scale: 1-healthy; 2-mild sign of lethargy and ruffled fur; 3-intermediate level of lethargy, ruffled fur and hunched posture; 4-very lethargy, ruffled fur, hunched posture and limited mobility; 5-moribund with limited to no mobility and inability to reach food or water [23]. Mice exhibiting weight loss more than $20 \%$ of initial body weight or moribund or paralyzed during the study were euthanized immediately [24] by open-drop exposure to $5 \%$ isoflurane administered in $1 \mathrm{~L}$ chamber volume. None of the mice died before meeting criteria for euthanasia. At the end of the study the survived mice were euthanized by open-drop exposure to isoflurane. The euthanization process was done in fume hood by the veterinarian.

\section{Dose determinations}

The dose was selected based on general toxicology studies conducted by Institute for Medical Research, Malaysia $[19,25]$. No mortality and adverse effect on the functions of the liver, kidney and bone marrow was observed in rats treated with up to $2000 \mathrm{mg} / \mathrm{kg} \mathrm{BW}$ FCPLJ. For cytokine screening, the treatment group was administered with daily doses of $500 \mathrm{mg} / \mathrm{kg}$ BW FCPLJ by oral route for 3 consecutive days. The mock infected and infected only groups were given distilled water. A second experiment was conducted for a concentration of $1000 \mathrm{mg} / \mathrm{kg}$ BW FCPLJ. For gene expression study, a similar group of mice were set up and the treatment group was given $1000 \mathrm{mg} /$ $\mathrm{kg} \mathrm{BW}$ of FCPLJ. General behavior and clinical signs were recorded daily. All experiments involving mice were performed in compliance with the guidelines of the Animal Care and Use Committee, Ministry of Health Malaysia (ACUC-MOH), ACUC/KKM/02(9/2016).

\section{Sample collections}

Two hundred microlitres of whole blood was collected in EDTA microtainer tube on day 3,5 and 7 post-infection by submandibular vein puncture technique. Blood smear was prepared from $2 \mu \mathrm{l}$ of whole blood and stained with Giemsa for blood differential count. For cytokine screening, plasma was separated from the whole blood by centrifugation for $15 \mathrm{~min}$ at $2000 \mathrm{x} \mathrm{g}$ at $4{ }^{\circ} \mathrm{C}$. The plasma was immediately transferred into a clean $1.5 \mathrm{ml}$ microcentrifuge tube and stored at $-80^{\circ} \mathrm{C}$ prior to be used for cytokine screening. For gene expression analysis, mice were euthanized on day 4 post-infection. Whole blood was collected by cardiac puncture directly in a syringe and transferred into EDTA microtainer tube. The blood was centrifuged for $15 \mathrm{~min}$ at $2000 \mathrm{x}$ g at $4{ }^{\circ} \mathrm{C}$ to obtain the plasma for the purpose of NS1 assay. Livers were harvested and kept in RNAlater $^{\text {Ti }}$ Stabilization Solution (Invitrogen, USA). The livers were kept at $-20^{\circ} \mathrm{C}$ until further use.

\section{Detection of NS1 production during dengue infection in AG129 mice}

The NS1 antigen detection in infected AG129 mice was done by using Platelia Dengue NS1 Ag kit (Bio-Rad Laboratories, USA). Plasma was diluted 1:10 with 1X PBS prior to the assay. Briefly, $50 \mu \mathrm{L}$ of sample and controls were diluted 1:2 with sample diluent and combined with $100 \mu \mathrm{L}$ of conjugate (anti-NS1 murine monoclonal antibodies (MAb) with horseradish peroxydase antibody). This solution was added to microtiter plates coated with anti-NS1 monoclonal antibodies and incubated at $37^{\circ} \mathrm{C}$ for $90 \mathrm{~min}$ followed by washing. When NS1 antigen was present, an immune-complex MAb-NS1-MAb-peroxidase formed and was exposed by adding a chromogenic substrate (tetramethylbenzidine and $\mathrm{H}_{2} \mathrm{O}_{2}$ ) to initiate color development. The reaction was halted by the addition of $100 \mu \mathrm{L}$ of stopping solution containing $1 \mathrm{~N}$ sulfuric acid and the optical density of samples was read at $450 \mathrm{~nm}$ using FLUOstar ${ }^{\oplus}$ Omega microplate reader (BMG Labtech, Germany).

\section{Cytokine screening and analysis}

A customized ProcartaPlex ${ }^{\mathrm{Tm}}$ Immunoassay Mouse Cytokine 12-plex (CSF3/G-CSF, CSF2/GM-CSF, IFN- $\gamma$, IL-1 $\beta$, IL-4, IL-6, IL-10, IL-13, CCL2/MCP-1, TNF- $\alpha$, CCL3/ MIP-1A and IL-18) was used to screen cytokine in $50 \mu \mathrm{l}$ of plasma according to manufacturer's instructions. Values for CSF2/GM-CSF, IL-1 $\beta$, IL-4, IL-10 and IL-13 were outside the detectable range for a majority of the experimental group samples and were excluded from the analysis.

\section{RNA isolation and CDNA synthesis}

Liver RNA isolation was performed by using the RNeasy Microarray Tissue Mini Kit (Qiagen, USA) following the manufacturer's protocol. Briefly, $30 \mathrm{mg}$ of tissue samples were homogenized using tissue ruptor and lysis buffer. 
The lysate was precipitated with $70 \%$ ethanol and washed twice with washing buffer. Finally the RNA pellet was dissolved in $50 \mu \mathrm{l}$ of RNase-free water. The isolated RNA was run through NanoDrop spectrophotometer (Thermo Fisher Scientific, USA) to determine both RNA yield and purity by measuring absorbance at 260 and $280 \mathrm{~nm}$. The RNA was reversely transcribed to complementary DNA sequence (cDNA) by using the $\mathrm{RT}^{2}$ First Strand Kit (Qiagen, USA) according to manufacturer's protocol. A starting amount of $1.5 \mu \mathrm{g}$ of total RNA was used for the reverse transcription process. In brief, the genomic DNA elimination reactions were performed in a final volume of $10 \mu$ using the buffer provided by the manufacturer and incubated at $42^{\circ} \mathrm{C}$ for 5 min. Then, $10 \mu \mathrm{l}$ of the reverse-transcription mix were added into each tube, followed by incubation at $42^{\circ} \mathrm{C}$ for $15 \mathrm{~min}$ and $95^{\circ} \mathrm{C}$ for $5 \mathrm{~min}$. The amplified cDNA was then diluted with nuclease-free water.

\section{Real-time PCR and gene expression analysis}

The level of gene expression in the liver was analyzed by using the Mouse Inflammatory Cytokines \& Receptors $\mathrm{RT}^{2}$ Profiler $^{\mathrm{nt}}$ PCR Array (PAMM-011Z; Qiagen, USA), which profiles the expression of 84 key genes encoding the inflammatory cytokines and receptors. The PCR mix was performed with the following mixture: $1350 \mu \mathrm{l}$ of $2 \mathrm{X}$ SYBR Green Master Mix, $102 \mu$ first-strand cDNA synthesis reaction and $1248 \mu \mathrm{l}$ of RNase-free water. A total of $25 \mu \mathrm{l}$ of the cocktail was added into each well of the $\mathrm{RT}^{2}$ Profiler PCR array plate.The real-time $\mathrm{qPCR}$ was performed using a 7500 Fast Real-Time PCR System (Applied Biosystems, USA) under the following thermal cycle condition: a start cycle for $10 \mathrm{~min}$ at $95^{\circ} \mathrm{C}, 40 \mathrm{cy}-$ cles of amplification $\left(15 \mathrm{~s}\right.$ at $95^{\circ} \mathrm{C}, 1 \mathrm{~min}$ at $60^{\circ} \mathrm{C}$ ) followed by a melt curve. The $\mathrm{Ct}$ values of the target cDNAs were normalized by the average $\mathrm{Ct}$ of 5 housekeeping genes (ACTB, B2M, GAPDH, GUSB and HSP90AB1) within the same plate. The PCR array was performed in singleton reaction for each sample.

\section{Statistical analysis}

For plasma cytokine, an ANOVA comparison analysis was done by using GraphPad Prism 7.0 Software. For gene expression analysis, data analysis was conducted using online $\mathrm{RT}^{2}$ Profiler PCR Array data analysis software provided by the manufacturer. The software used the $\Delta \Delta \mathrm{Ct}$ method to calculate the fold change between the experimental groups. Statistical analysis was done using two-tailed Student's t-test. $P$-value $<0.05$ was considered statistically significant difference.

\section{Results}

HPLC fingerprint analysis of FCPLJ

Four peaks of major compounds were determined in the FCLPJ by HPLC (Fig. 1). These compounds were identified as manghaslin, clitorin, rutin and nicotiflorin by using standard with retention time of 11.50, 12.53, 13.50 and 15.10 , respectively (Table 1 ).

\section{Effect of FCPLJ treatment on plasma NS1 level}

All AG129 mice from infected groups started developing viremia after the inoculation of dengue virus. The dengue virus in the infected group was confirmed by the presence of high NS1 level in the plasma. The plasma NS1 level of the infected AG129 mice started to peak on day 3 post infection and began to decline in between day 5 and day 7 post infection (Fig. 2). The mock infected group showed negligible level of plasma NS1. High level of plasma NS1 was also observed in the FCPLJ treated group, suggesting that the FCPLJ treatment has no effect on the plasma NS1 level in the infected AG129 mice. Similar NS1 level between infected and treatment groups was also observed in the gene expression animal group euthanized on day 4 of post infection (Additional file 1: Figure S1).

\section{Effect of FCPLJ treatment on leukocyte, cytokine and chemokine responses in AG129 mice infected with dengue virus}

The leukocyte count in AG129 mice was increased during the dengue virus infection. In addition, the neutrophil percentage was increased while the lymphocyte percentage was decreased during dengue virus infection (Additional file 2: Table S1). However, the FCPLJ treatment (500 and $1000 \mathrm{mg} / \mathrm{kg} \mathrm{BW}$ ) did not significantly affect the leukocyte's level as compared to infected group. The effect of FCPLJ treatment on cytokines level was investigated in AG129 mice on day 3, day 5 and day 7 post-infection. The results showed that the level of inflammatory cytokines (G-CSF, IFN- $\gamma$, IL-6, IL-18, MCP-1 and TNF- $\alpha$ ) in infected group were higher as compared to mock infected AG129 mice group (Fig. 3 and Additional files 3 and 4: Figure S2-S3). The treatment of FCPLJ (500 and $1000 \mathrm{mg} / \mathrm{kg} \mathrm{BW}$ ) has significantly increased MCP-1 level $(p<0.05)$ (Fig. 3). Other cytokines such as G-CSF, IL-6, and TNF- $\alpha$ were apparently increased by FCPLJ treatment especially on day 3 post infection (Additional files 3 and 4: Figure S2 and S3).

\section{Effect of FCPLJ treatment on gene expression profile of inflammatory cytokines and receptors in the liver of AG129 mice infected with dengue virus}

As compared to mock infected group, a total of 26 genes were upregulated in the liver of AG129 mice infected with dengue virus (Additional file 5: Table S2). The number of upregulated genes were decreased to 22 genes in the liver of FCPLJ treated AG129 mice infected with dengue virus. As compared to the infected group, there was a significant downregulation of 8 genes in the 


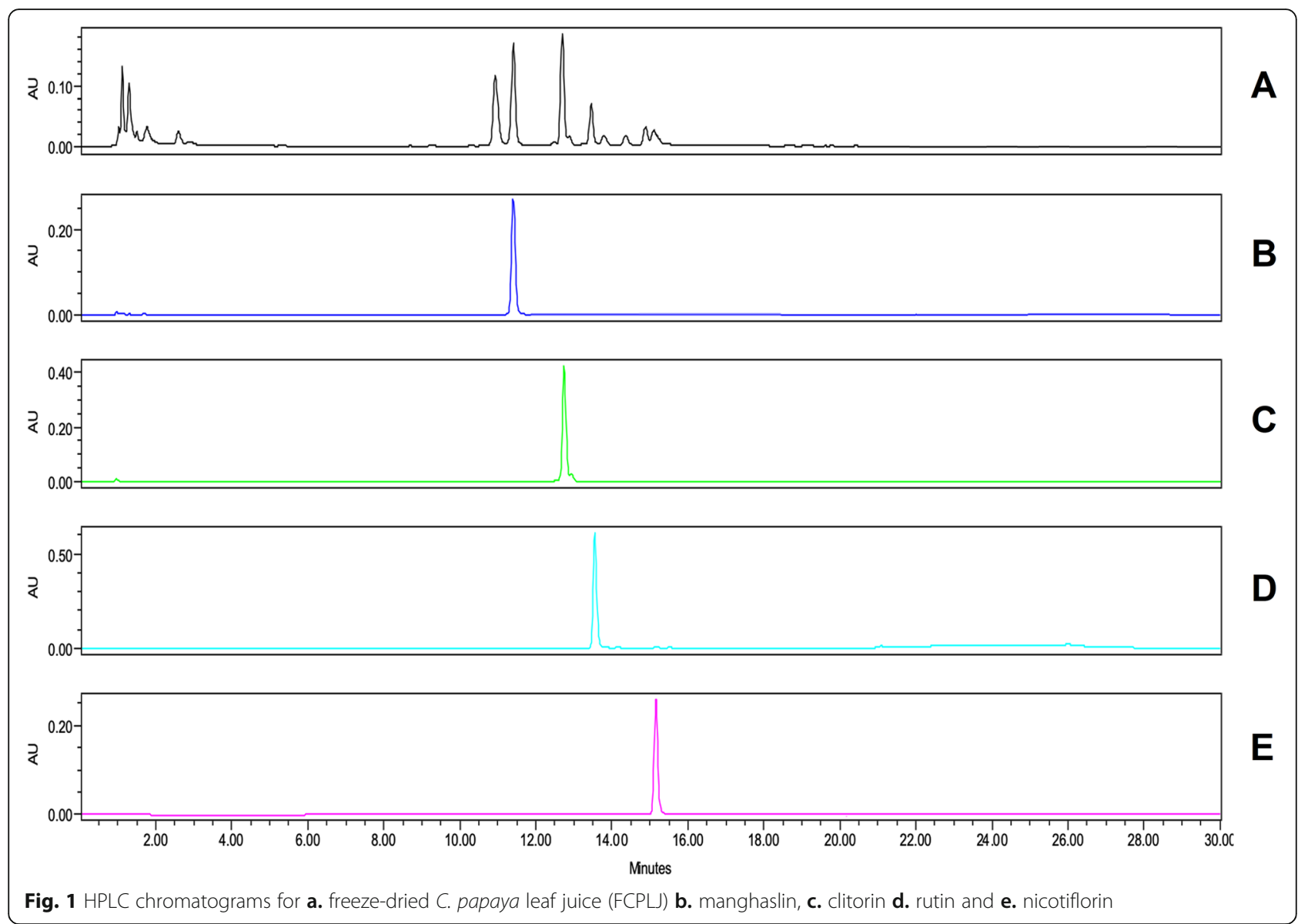

liver of FCPLJ treated AG129 mice infected with dengue virus. These genes were CCL6/MRP-1, CCL8/MCP-2, CCL12/MCP-5, CCL17/TARC, IL1R1, IL1RN/IL1Ra, NAMPT/PBEF1 and PF4/CXCL4 (Fig. 4 and Table 2).

\section{Discussion}

Four flavonoid compounds; manghaslin with retention time at $11.50 \mathrm{~min}$, clitorin at $12.53 \mathrm{~min}$, rutin at 13.50 min and nicotiflorin at $15.10 \mathrm{~min}$ were identified in FCPLJ samples. The retention time of each compound was decreased along with high molecular weight of the compound corresponding to diverse range of adsorption affinities. Several studies have identified these flavonoid compounds in FCPLJ, in which manghaslin and clitorin were found to be highly abundant flavonoid compounds in the leaves [19-21, 26]. These four compounds were also found to be high in butanol fraction compared to methanol extract of FCPLJ samples [21]. It has been reported that flavonoids have potent immunomodulatory activities and antiviral properties [27-29].

In the present study, AG129 mice in the infected group were inoculated with $2 \times 10^{6}$ PFU dengue virus DEN-2. The infection was confirmed by assessing the NS1 level in plasma samples. Our initial observation found that the NS1 level started to peak at day 3 of post infection and was almost absent at day 7 of post infection. It has been reported that serum or plasma dengue virus NS1 level correlates with viremia titer and severity of the disease [30,31]. Treatment with FCPLJ in this study does not stop the progress of viremia

Table 1 Compound identification in freeze-dried Carica papaya leaf juice

\begin{tabular}{|c|c|c|c|}
\hline Compounds & Molecular formula & $\begin{array}{l}\text { Molecular weight, } \\
\mathrm{gmol}^{-1}\end{array}$ & Retention time (RT), min \\
\hline Manghaslin & $\mathrm{C}_{33} \mathrm{H}_{40} \mathrm{O}_{20}$ & 756.66 & 11.50 \\
\hline Clitorin & $\mathrm{C}_{33} \mathrm{H}_{40} \mathrm{O}_{19}$ & 740.66 & 12.53 \\
\hline Rutin & $\mathrm{C}_{27} \mathrm{H}_{30} \mathrm{O}_{16}$ & 610.52 & 13.50 \\
\hline Nicotiflorin & $\mathrm{C}_{27} \mathrm{H}_{32} \mathrm{O}_{15}$ & 596.53 & 15.10 \\
\hline
\end{tabular}




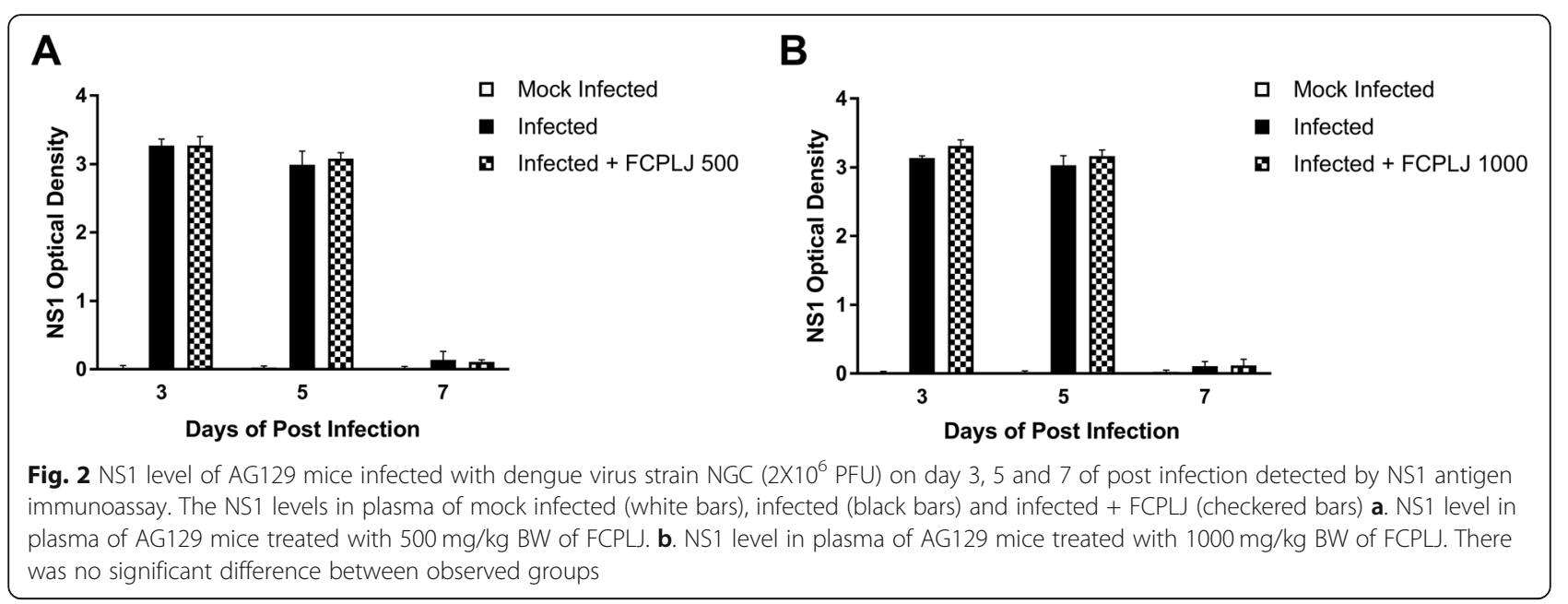

development, therefore suggesting that FCPLJ does not have direct effect on the virus.

The possible in vivo immunomodulatory effect of FCPLJ was detected in the present study by the increase in plasma cytokines particularly the CCL2/ MCP-1 in dengue virus infected AG129 mice treated with $500 \mathrm{mg} / \mathrm{kg}$ BW and $1000 \mathrm{mg} / \mathrm{kg}$ BW FCPLJ. The importance of CCL2/MCP-1 in dengue infection has been reported in many studies involving AG129 dengue mouse model where the cytokine was found to be increased during infection [24, 32-34]. The CCL2/MCP-1 has its role in macrophage and monocyte recruitments to the site of infection. This molecule is produced by a variety of cell types including fibroblasts, cardiomyocytes, endothelial and smooth muscle cells, and monocytic cells; either constitutively or after induction by oxidative stress, cytokines and growth factors [35]. In dengue infection, platelet -monocyte aggregation was induced in dengue patients and the aggregate formation could enhanced the production of cytokines and chemokines by monocytes including TNF- $\alpha$, IL-1b, IL-8, and CCL2/MCP-1 [36].

Histopathological changes in liver of human dengue fatal cases have been reported [37-39]. Many in vitro studies have demonstrated that the infection of dengue virus in hepatoma cell lines [40-42] lead to important dengue-host interaction; including stimulation of innate immunity, apoptosis, induction of cytokine and chemokine [43]. We assessed the effect of FCPLJ on the induction of inflammatory cytokine gene expression in liver during dengue virus infection in AG129 mice. Our study revealed a significant upregulation of 26 genes in the liver following the infection with DEN2 in AG129 mice
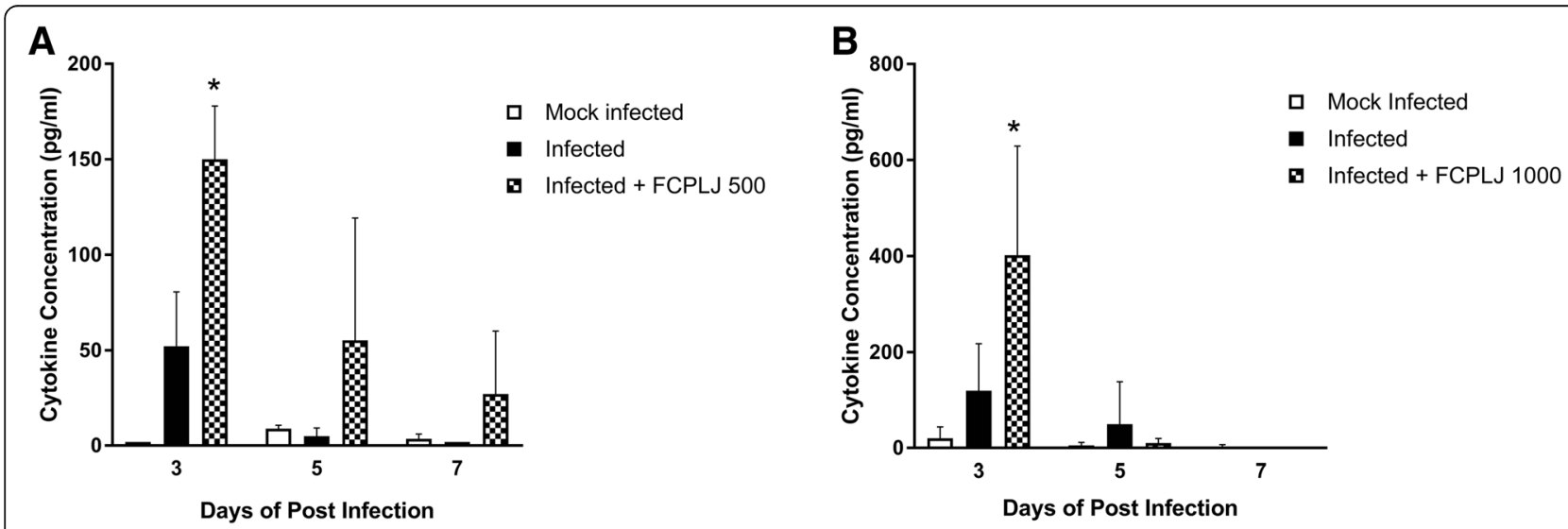

Fig. 3 The freeze-dried C. papaya leaf juice (FCPLJ) increased the monocyte chemoattractant protein 1 (CCL2/MCP-1) in the plasma of AG129 mice infected with dengue virus. The CCL/MCP-1 cytokine level in plasma collected from mock infected (white bars), infected (black bars) and infected + FCPL (checkered bars) AG129 mice groups at day 3, day 5 and day 7 post-infection were analyzed by Procartaplex immunoassay. Bars represent the mean values \pm SEM. The cytokine level was compared between experimental groups using ANOVA multiple comparison test. a. CCL/MCP-1 level in plasma of AG129 mice treated with 500 mg/kg BW of FCPLJ. b. CCL/MCP-1 level in plasma of AG129 mice treated with 1000 $\mathrm{mg} / \mathrm{kg} \mathrm{BW}$ of FCPLJ. Astrisk $\left(^{*}\right)$ denotes as significant difference at $P$ value $<0.05$ 


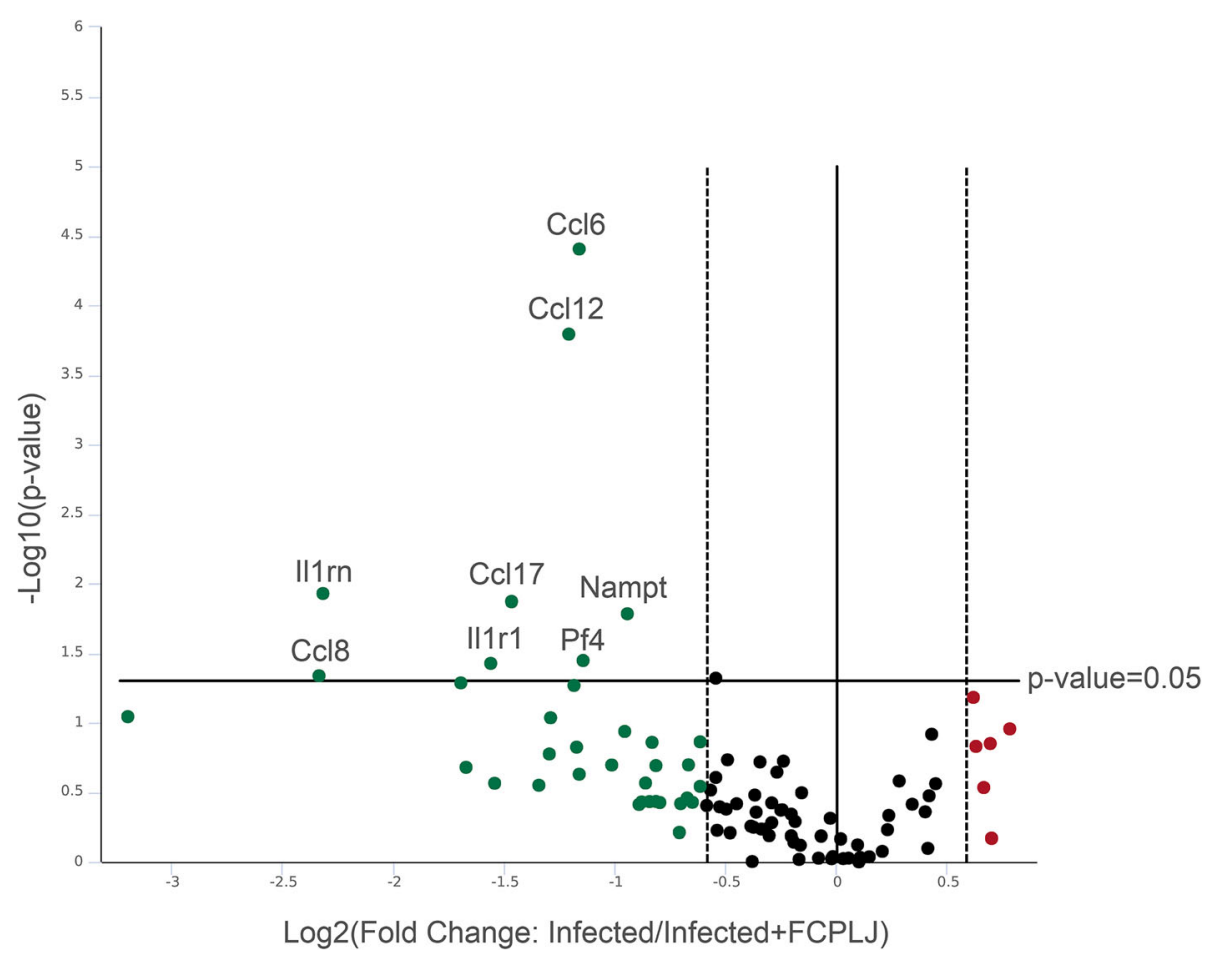

Fig. 4 The freeze-dried C. papaya leaf juice (FCPLJ) effects on gene expression of inflammatory cytokines and receptors in the liver of AG129 mice infected with dengue virus on day 4 of post-infection. The volcano plot showing the fold change for each of the 84 genes in the array: upregulated (red dots), unchanged (black dots) and downregulated (green dots). Genes, which were significantly downregulated $(P<0.05)$ in infected + FCPL group in comparison with infected group, were indicated

compared to healthy control group. Treatment with $1000 \mathrm{mg} / \mathrm{kg}$ BW FCPLJ in infected group showed a decrease number of significant upregulated genes to 22 . Similar with the elevated level of CCL2/MCP-1 level in plasma cytokine on day 3, upregulation of CCL2/MCP-1 was also observed in the liver of treated group (Infected + FCPLJ) as compared to infected group, although the increase was not significant (Table S2).

As compared to the infected group, the FCPLJ treatment showed significant downregulation of these 8 genes; CCL6/MRP-1, CCL8/MCP-2, CCL12/MCP-5, CCL17/TARC, IL1R1, IL1RN/IL1Ra, NAMPT/PBEF1 and PF4/CXCL4. CCL6/MRP-1, CCL12/MCP-5, and IL1R1 have not been previously described in dengue virus infections in vitro or in patients. A strong stimulation of CCL8/MCP-2 has been reported in human primary monocytes, B cells and dendritic cells infected with dengue virus in vitro [44]. Due to its various binding receptors such as CCR1, CCR2 and CCR5, CCL8/ MCP-2 may have independent effects on immune

Table 2 Cytokines and receptors showing significant differential gene expression level in the liver of infected AG129 mice treated with FCPLJa compared to infected AG129 mice without treatment

\begin{tabular}{llll}
\hline Gene target & Description & Fold regulation $^{\text {b }}$ & $P$ value $^{c}$ \\
\hline CCL12 & Chemokine (c-c motif) ligand 12 & -2.31 & 0.000161 \\
CCL17 & Chemokine (c-c motif) ligand 17 & -2.76 & 0.013469 \\
CCL6 & Chemokine (c-c motif) ligand 6 & -2.23 & 0.000039 \\
CCL8 & Chemokine (c-c motif) ligand 8 & -5.05 & 0.045934 \\
ILIR1 & Interleukin-1 receptor, type 1 & -2.95 & 0.037396 \\
ILIRN & Interleukin-1 receptor antagonist & -4.99 & 0.011812 \\
NAMPT & Nicotinamide phosphoribosyltransferase & -1.92 & 0.016427 \\
PF4 & Platelet factor 4 & -2.21 & 0.035662
\end{tabular}

${ }^{a}$ Freeze-dried Carica papaya leaf juice; dengue virus infected AG129 mice were given $1000 \mathrm{mg} / \mathrm{kg}$ BW

${ }^{\text {b}}$ The fold regulation cut off is 1.5

${ }^{\mathrm{C}}$ Gene expression are considered to show significant differential expression at a $P$ value of $<0.05$ 
response to dengue virus infection by engaging with different receptors to activate or suppress the effect of other chemokines. The upregulation of CCL17/TARC was reported in the spleen of dengue virus infected mice [45]. Elevated levels of anti-inflammatory cytokine IL1RN/IL1Ra was previously observed in dengue patients $[46,47]$ and IL1RN/IL1Ra level was higher in dengue with the warning signs patients compared to the dengue without the warning signs patients [48]. Downregulation of PF4/CXCL4 gene by two folds following the treatment with FCPLJ in dengue infected mice in this study showed that FCPLJ could has suppressed the expression of PF4/CXCL4 gene to increase platelet production during dengue infection. There was an evidence showing that PF4/CXCL4 as an in vivo negative autocrine regulator of platelet production [49]. Furthermore, it was reported that PF4/CXCL4 was increased in plasma of dengue patients compared to healthy volunteers [50]. The upregulation of NAMPT/PBEF1 in dengue virus infected mice was in concurrence with the finding of previous in vivo study [51]. The function of NAMPT/PBEF1 as an inflammatory cytokine has been implicated in other acute and chronic inflammatory conditions [52] and has been shown to upregulate several prominent inflammatory cytokines such as IL-6, TNF- $\alpha$, IL-1 $\beta$, and, more recently, TGF- $\beta 1$ [53].

Previous studies have reported a relationship between high levels of pro-inflammatory cytokine production with severity of the dengue disease. [54, 55]. Although the mechanism of the disease pathogenesis has not been clarified, it has been implied that the released of cytokines and other mediators during the immune response to dengue virus infection, may contribute for the increased permeability of vascular endothelial cells [44, 56]. Therefore, the effect of FCPLJ treatment to downregulate certain genes as demonstrated in this study suggested that FCPLJ may serve as potential immunomodulator of host immune responses during dengue virus infection.

In this study, although all samples were accounted and tested for cytokine levels, certain cytokines were undetectable in some samples. The study focused on the plasma and liver cytokines. Other organs such as spleen, kidney, heart, lung and brain were not included in our analysis. Therefore, we might leave out what could be important informations of FCPLJ effect on cytokines level in other vital organs. This study could not highlight the functional activities of the affected cytokines. In order to validate the finding of this study, further analysis such as histology stain of the liver, protein expression or immunohistochemistry analysis need to be conducted in future studies. As the FCPLJ has been proven as a thrombocytosis agent, the information on its mechanism of action in enhancing platelet production and immunomodulatory activity during dengue infection could be interesting subject to explore further.

\section{Conclusion}

The present study has generated an initial data highlighting the possible function of FCPLJ in modulating the release of certain cytokines during dengue infection in infected AG129 mice specifically the CCL2/ MCP-1 level during peak of viremia. FCPLJ treatment has also downregulated inflammatory cytokine genes such as CCL6/MRP-1, CCL8/MCP-2, CCL12/MCP-5, CCL17/TARC, IL1R1, IL1RN/IL1Ra, NAMPT/PBEF1 and PF4/CXCL4 in the liver of infected AG129 mice. More studies are still necessary to address the specific immunomodulatory role played by FCPLJ during dengue infection.

\section{Additional files}

Additional file 1: Figure S1. NS1 level of AG129 mice infected with dengue virus ( $\left.2 \times 10^{6} \mathrm{PFU}\right)$ on day 4 of post infection detected by NS1 antigen immunoassay. (PDF $58 \mathrm{~kb}$ )

Additional file 2: Table S1. Total white blood cells and differential counts of AG129 mice infected with dengue virus. (PDF 39 kb)

Additional file 3: Figure S2. The cytokine level in plasma of dengue virus infected AG129 mice treated with 500 mg/kg BW of FCPL. (PDF 151 kb)

Additional file 4: Figure S3. The cytokine level in plasma of dengue virus infected AG129 mice treated with $1000 \mathrm{mg} / \mathrm{kg}$ BW of FCPL. (PDF $133 \mathrm{~kb}$ )

Additional file 5: Table S2. Fold Regulation of 84 genes associated with mouse inflammatory cytokines \& receptors. (PDF $75 \mathrm{~kb}$ )

\section{Abbreviations}

IFN-ץ: Interferon gamma; DMEM: Dulbecco's modified eagle's medium; ACTB: Actin B; ANOVA: Analysis of variance; B2M: Beta-2-microglobulin; BW: Body weight; CCL12/MCP-5: Chemokine (C-C motif) ligand 12/monocyte chemoattractant protein-5; CCL17/TARC: Chemokine (c-c motif) ligand 17/ thymus and activation-regulated chemokine; CCL2/MCP-1: Chemokine (C-C motif) ligand 2/monocyte chemoattractant protein-1; CCL3/MIP-

1A: Chemokine (c-c motif) ligand 3/macrophage inflammatory protein 1alpha; CCL6/MRP-1: Chemokine (c-c motif) ligand 6/multidrug resistanceassociated protein 1; CCL8/MCP-2: Chemokine (c-c motif) ligand 8/monocyte chemoattractant protein-2; CDNA: Complementary DNA sequence; CPLJ: C. papaya leaf juice; CSF2/GM-CSF: Colony stimulating factor 2/granulocytemacrophage colony-stimulating factor; CSF3/G-CSF: Colony stimulating factor 3/granulocyte-colony stimulating factor; DEN-2: Dengue virus type;

EDTA: Ethylenediaminetetraacetic acid; FCPLJ: Freeze-dried C. papaya leaf juice; GAPDH: Glyceraldehyde-3-phosphate dehydrogenase;

GUSB: Glucuronidase beta; HPLC: High performance liquid chromatography; HSP90AB1: Heat shock protein 90 alpha family class b member; I IL1RN/ IL1Ra: Interleukin-1 receptor antagonist; IL-10: Interleukin 10; IL-13: Interleukin 13; IL-18: Interleukin 18; IL1R1: Interleukin-1 receptor type; IL-1 $\beta$ : Interleukin 1, beta; IL-4: Interleukin 4; IL-6: Interleukin-6; NAMPT/PBEF1: Nicotinamide phosphoribosyltransferase/pre-b-cell colony-enhancing factor 1; NS1: Nonstructural protein 1; PBMCs: Peripheral blood mononuclear cells; PCR: Polymerase chain reaction; PF4/CXCL4: Platelet factor 4/chemokine ( $c-X-$ c motif) ligand 4; PFU: Plaque forming units; RNA: Ribonucleic acid; TFA: Trifluoroacetic acid; TNF-a: Tumor necrosis factor alpha

\section{Acknowledgements}

The authors would like to thank the Director General of Health Malaysia for permission to publish this paper. We thank the Director for the Institute for Medical Research (IMR), Kuala Lumpur for her critical review and support in publishing this paper. The authors also wish to thank the staff of Bioassay, 
Phytochemistry and Toxicology and Pharmacology Units, Herbal Medicine Research Centre, IMR, Kuala Lumpur who has contributed in this study.

\section{Funding}

This research was supported by the grant from Ministry of Health Malaysia under project number NMRR-15-2188-27661 (JPP-IMR 15-019).

\section{Availability of data and materials}

The datasets used and/or analyzed during the current study are available from the corresponding authors upon reasonable request.

\section{Authors' contributions}

NAN and MRMAR designed the study, performed all experiments and data analysis, interpretation of results and drafted the manuscript. NMM prepared and analysed the FCPL fingerprinting. NHMJ conducted the dengue virus propagation. URS, AM, THCD, BJ and NAZ involved in the animal experiments and samples collection. RT supervised the experimental design related to dengue virus. AMR supervised the cytokine and gene expression data intepretation and help improved the manuscript. MZ supervised the experimental design for animal study. AFSM overlook overall experimental design and corrected the draft of manuscript. All authors have read and approved the final manuscript.

\section{Ethics approval and consent to participate}

All the animal experiments were carried out under the guidelines and upon approval of the Animal Care and Use Committee, Ministry of Health Malaysia (ACUC-MOH), ACUC/KKM/02(9/2016).

\section{Consent for publication}

Not applicable.

\section{Competing interests}

The authors declare that they have no competing interests.

\section{Publisher's Note}

Springer Nature remains neutral with regard to jurisdictional claims in published maps and institutional affiliations.

\section{Author details}

${ }^{1}$ Herbal Medicine Research Center, Institute for Medical Research, Ministry of Health Malaysia, 50588 Kuala Lumpur, Malaysia. ${ }^{2}$ Infectious Disease Research Center, Institute for Medical Research, Ministry of Health Malaysia, 50588 Kuala Lumpur, Malaysia. ${ }^{3}$ Allergy and Immunology Research Center, Institute for Medical Research, Ministry of Health Malaysia, 50588 Kuala Lumpur, Malaysia.

Received: 23 August 2018 Accepted: 14 January 2019

Published online: 11 February 2019

\section{References}

1. Bhatt S, Gething PW, Brady OJ, Messina JP, Farlow AW, Moyes CL, Drake JM, Brownstein JS, Hoen AG, Sankoh O, et al. The global distribution and burden of dengue. Nature. 2013;496(7446):504-7.

2. WHO. Dengue Haemorrhagic fever: diagnosis, treatment, prevention and control. Geneva. Switzerland: World Health Organization; 1997.

3. Tsai S, Santamaria P. MHC class II polymorphisms, autoreactive T-cells, and autoimmunity. Front Immunol. 2013:4:321.

4. Guabiraba R, Ryffel B. Dengue virus infection: current concepts in immune mechanisms and lessons from murine models. Immunology. 2014;141(2): 143-56.

5. Sathasivam K, Ramanathan S, Mansor SM, Haris MR, Wernsdorfer WH. Thrombocyte counts in mice after the administration of papaya leaf suspension. Wien Klin Wochenschr. 2009:121(Suppl 3):19-22.

6. Gammulle A, Ratnasooriya WD, Jayakody JRAC, Fernando C, Kanatiwela C, Udagama PV. Thrombocytosis and anti-inflammatory properties and toxicology evaluation of Carica papaya mature leaf concentrate in a murine model. Online International Journal of Medicinal Plants Research. 2012;1(2): 21-30.

7. Dharmarathna SL, Wickramasinghe S, Waduge RN, Rajapakse RP, Kularatne SA. Does Carica papaya leaf-extract increase the platelet count? An experimental study in a murine model. Asian Pac J Trop Biomed. 2013;3(9): 720-4.

8. Patil S, Shetty S, Bhide R, Narayanan S. Evaluation of Platelet Augmentation Activity of Carica papaya Leaf Aqueous Extract in Rats. Journal of Pharmacognosy and Phytochemistry. 2013;1(5):57-60.

9. Hettige S. Salutary effects of carica papaya leaf extract in dengue fever patients - a pilot study. Sri Lankan Family Physician. 2008;29:17-9.

10. Ahmad N, Fazal H, Ayaz M, Abbasi BH, Mohammad I, Fazal L. Dengue fever treatment with Carica papaya leaves extracts. Asian Pac J Trop Biomed. 2011;1(4):330-3.

11. Yunita F, Hanani E. The effect of Carica papaya $L$ leaves extract capsule on platelet count and hematocrit level in dengue fever patient. Int J Med Aromat Plants. 2012:2:573-8.

12. Subenthiran S, Choon TC, Cheong KC, Thayan R, Teck MB, Muniandy PK, Afzan A, Abdullah NR, Ismail Z. Carica papaya leaves juice significantly accelerates the rate of increase in platelet count among patients with dengue fever and dengue Haemorrhagic fever. Evid Based Complement Alternat Med. 2013;2013 616737.

13. Siddique O, Sundus A, Ibrahim MF. Effects of papaya leaves on thrombocyte counts in dengue--a case report. JPMA The Journal of the Pakistan Medical Association. 2014:64(3):364-6.

14. Otsuki N, Dang NH, Kumagai E, Kondo A, Iwata S, Morimoto C. Aqueous extract of Carica papaya leaves exhibits anti-tumor activity and immunomodulatory effects. J Ethnopharmacol. 2010;127(3):760-7.

15. Sagnia B, Fedeli D, Casetti R, Montesano C, Falcioni G, Colizzi V. Antioxidant and anti-inflammatory activities of extracts from Cassia alata, Eleusine indica, Eremomastax speciosa, Carica papaya and Polyscias fulva medicinal plants collected in Cameroon. PLoS One. 2014;9(8):e103999.

16. Anjum V, Arora P, Ansari SH, Najmi AK, Ahmad S. Antithrombocytopenic and immunomodulatory potential of metabolically characterized aqueous extract of Carica papaya leaves. Pharm Biol. 2017;55(1):2043-56.

17. Jayasinghe CD, Gunasekera DS, De Silva N, Jayawardena KKM, Udagama PV. Mature leaf concentrate of Sri Lankan wild type Carica papaya Linn. Modulates nonfunctional and functional immune responses of rats. BMC Complement Altern Med. 2017;17(1):230.

18. Afolabi IS, Osikoya IO, Fajimi OD, Usoro PI, Ogunleye DO, Bisi-Adeniyi T, Adeyemi AO, Adekeye BT. Solenostemon monostachyus, Ipomoea involucrata and Carica papaya seed oil versus glutathione, or Vernonia amygdalina: methanolic extracts of novel plants for the management of sickle cell anemia disease. BMC Complement Altern Med. 2012;12:262.

19. Afzan A, Abdullah NR, Halim SZ, Rashid BA, Semail RH, Abdullah N, Jantan I, Muhammad H, Ismail Z. Repeated dose 28-days oral toxicity study of Carica papaya L. leaf extract in Sprague Dawley rats. Molecules. 2012;17(4):4326-42.

20. Julianti T, De Mieri M, Zimmermann S, Ebrahimi SN, Kaiser M, Neuburger M, Raith M, Brun R, Hamburger M. HPLC-based activity profiling for antiplasmodial compounds in the traditional Indonesian medicinal plant Carica papaya L. J Ethnopharmacol. 2014;155(1):426-34.

21. Nugroho A, Heryani $\mathrm{H}$, Choi JS, Park H-J. Identification and quantification of flavonoids in Carica papaya leaf and peroxynitrite-scavenging activity. Asian Pacific Journal of Tropical Biomedicine. 2017;7(3):208-13.

22. McCormick KD, Liu S, Jacobs JL, Marques ET, Jr Sluis-Cremer N, Wang T. Development of a robust cytopathic effect-based high-throughput screening assay to identify novel inhibitors of dengue virus. Antimicrob Agents Chemother. 2012;56(6):3399-401.

23. Orozco S, Schmid MA, Parameswaran P, Lachica R, Henn MR, Beatty R, Harris E. Characterization of a model of lethal dengue virus 2 infection in C57BL/6 mice deficient in the alpha/beta interferon receptor. J Gen Virol. 2012;93(Pt 10):2152-7.

24. Milligan GN, Sarathy W, Infante E, Li L, Campbell GA, Beatty PR, Harris E, Barrett $A D$, Bourne N. A dengue virus type 4 model of disseminated lethal infection in AG129 mice. PLoS One. 2015;10(5):e0125476.

25. Ismail Z, Halim SZ, Abdullah NR, Afzan A, Abdul Rashid BA, Jantan I. Safety evaluation of Oral toxicity of Carica papaya Linn. Leaves: a subchronic toxicity study in Sprague Dawley rats. Evid Based Complement Alternat Med. 2014;2014 741470.

26. Nguyen TT, Parat MO, Hodson MP, Pan J, Shaw PN, Hewavitharana AK Chemical characterization and in vitro cytotoxicity on squamous cell carcinoma cells of Carica papaya leaf extracts. Toxins. 2015:8(1).

27. Zandi K, Teoh BT, Sam SS, Wong PF, Mustafa MR, Abubakar S. Antiviral activity of four types of bioflavonoid against dengue virus type-2. Virol J. 2011;8:560. 
28. Li Y, Yao J, Han C, Yang J, Chaudhry MT, Wang S, Liu H, Yin Y. Quercetin, inflammation and immunity. Nutrients. 2016;8(3):167.

29. Zakaryan H, Arabyan E, Oo A, Zandi K. Flavonoids: promising natural compounds against viral infections. Arch Virol. 2017;162(9):2539-51.

30. Hang VT, Nguyet NM, Trung DT, Tricou V, Yoksan S, Dung NM, Van Ngoc T, Hien TT, Farrar J, Wills B, et al. Diagnostic accuracy of NS1 ELISA and lateral flow rapid tests for dengue sensitivity, specificity and relationship to viraemia and antibody responses. PLoS Negl Trop Dis. 2009;3(1):e360.

31. Vaughn DW, Green S, Kalayanarooj S, Innis BL, Nimmannitya S, Suntayakorn S, Endy TP, Raengsakulrach B, Rothman AL, Ennis FA, et al. Dengue viremia titer, antibody response pattern, and virus serotype correlate with disease severity. J Infect Dis. 2000;181(1):2-9.

32. Sarathy W, Infante E, Li L, Campbell GA, Wang T, Paessler S, Robert Beatty P, Harris E, Milligan GN, Bourne N, et al. Characterization of lethal dengue virus type 4 (DENV-4) TVP-376 infection in mice lacking both IFN-alpha/beta and IFN-gamma receptors (AG129) and comparison with the DENV-2 AG129 mouse model. J Gen Virol. 2015:96(10):3035-48.

33. Sarathy W, White M, Li L, Gorder SR, Pyles RB, Campbell GA, Milligan GN, Bourne N, Barrett AD. A lethal murine infection model for dengue virus 3 in AG129 mice deficient in type I and II interferon receptors leads to systemic disease. J Virol. 2015:89(2):1254-66.

34. Phanthanawiboon S, Limkittikul K, Sakai Y, Takakura N, Saijo M, Kurosu T. Acute systemic infection with dengue virus leads to vascular leakage and death through tumor necrosis factor-alpha and Tie2/angiopoietin signaling in mice lacking type I and II interferon receptors. PLoS One. 2016;11(2): e0148564.

35. Deshmane SL, Kremlev S, Amini S, Sawaya BE. Monocyte chemoattractant protein-1 (MCP-1): an overview. J Interf Cytokine Res. 2009;29(6):313-26.

36. Hottz ED, Medeiros-de-Moraes IM, Vieira-de-Abreu A, de Assis EF, Vals-deSouza R, Castro-Faria-Neto HC, Weyrich AS, Zimmerman GA, Bozza FA, Bozza PT. Platelet activation and apoptosis modulate monocyte inflammatory responses in dengue. J Immunol. 2014;193(4):1864-72.

37. Couvelard A, Marianneau P, Bedel C, Drouet MT, Vachon F, Henin D, Deubel $V$. Report of a fatal case of dengue infection with hepatitis: demonstration of dengue antigens in hepatocytes and liver apoptosis. Hum Pathol. 1999; 30(9):1106-10

38. Huerre MR, Lan NT, Marianneau P, Hue NB, Khun H, Hung NT, Khen NT, Drouet MT, Huong VT, Ha DQ, et al. Liver histopathology and biological correlates in five cases of fatal dengue fever in Vietnamese children. Virchows Arch. 2001;438(2):107-15.

39. Povoa TF, Alves AM, Oliveira CA, Nuovo GJ, Chagas VL, Paes MV. The pathology of severe dengue in multiple organs of human fatal cases: histopathology, ultrastructure and virus replication. PLoS One. 2014;9(4): e83386

40. Lin YL, Liu CC, Lei HY, Yeh TM, Lin YS, Chen RM, Liu HS. Infection of five human liver cell lines by dengue-2 virus. J Med Virol. 2000;60(4):425-31.

41. Cabrera-Hernandez A, Thepparit C, Suksanpaisan L, Smith DR. Dengue virus entry into liver (HepG2) cells is independent of hsp90 and hsp70. J Med Virol. 2007;79(4):386-92.

42. Heaton NS, Randall G. Dengue virus-induced autophagy regulates lipid metabolism. Cell Host Microbe. 2010;8(5):422-32.

43. Sung JM, Lee CK, Wu-Hsieh BA. Intrahepatic infiltrating NK and CD8 T cells cause liver cell death in different phases of denque virus infection. PLoS One. 2012;7(9):e46292.

44. Becerra A, Warke RV, Martin K, Xhaja K, de Bosch N, Rothman AL, Bosch I. Gene expression profiling of dengue infected human primary cells identifies secreted mediators in vivo. J Med Virol. 2009:81 (8):1403-11.

45. Guabiraba R, Marques RE, Besnard AG, Fagundes CT, Souza DG, Ryffel B, Teixeira MM. Role of the chemokine receptors CCR1, CCR2 and CCR4 in the pathogenesis of experimental dengue infection in mice. PLoS One. 2010; 5(12):e15680.

46. de-Oliveira-Pinto LM, Gandini M, Freitas LP, Siqueira MM, Marinho CF, Setubal S, Kubelka CF, Cruz OG, Oliveira SA. Profile of circulating levels of IL1Ra, CXCL10/IP-10, CCL4/MIP-1 beta and CCL2/MCP-1 in dengue fever and parvovirosis. Mem Inst Oswaldo Cruz. 2012;107(1):48-56.

47. Suharti C, van Gorp EC, Dolmans WM, Setiati TE, Hack CE, Djokomoeljanto R, van der Meer JW. Cytokine patterns during dengue shock syndrome. Eur Cytokine Netw. 2003;14(3):172-7.

48. Rathakrishnan A, Wang SM, Hu Y, Khan AM, Ponnampalavanar S, Lum LC, Manikam R, Sekaran SD. Cytokine expression profile of dengue patients at different phases of illness. PLoS One. 2012;7(12):e52215.
49. Lambert MP, Rauova L, Bailey M, Sola-Visner MC, Kowalska MA, Poncz M. Platelet factor 4 is a negative autocrine in vivo regulator of megakaryopoiesis: clinical and therapeutic implications. Blood. 2007;110(4): $1153-60$

50. Trugilho MRO, Hottz ED, Brunoro GVF, Teixeira-Ferreira A, Carvalho PC, Salazar GA, Zimmerman GA, Bozza FA, Bozza PT, Perales J. Platelet proteome reveals novel pathways of platelet activation and platelet-mediated immunoregulation in dengue. PLoS Pathog. 2017;13(5):e1006385.

51. Morrison J, Rathore APS, Mantri CK, Aman SAB, Nishida A, St John AL. Transcriptional profiling confirms the therapeutic effects of mast cell stabilization in a dengue disease model. J Virol. 2017;91(18).

52. Luk T, Malam Z, Marshall JC. Pre-B cell colony-enhancing factor (PBEF)/ visfatin: a novel mediator of innate immunity. J Leukoc Biol. 2008;83(4):80416.

53. Sun Z, Lei H, Zhang Z. Pre-B cell colony enhancing factor (PBEF), a cytokine with multiple physiological functions. Cytokine Growth Factor Rev. 2013; 24(5):433-42.

54. Pang T, Cardosa MJ, Guzman MG. Of cascades and perfect storms: the immunopathogenesis of dengue haemorrhagic fever-dengue shock syndrome (DHF/DSS). Immunol Cell Biol. 2007;85(1):43-5.

55. Chaturvedi UC, Elbishbishi EA, Agarwal R, Raghupathy R, Nagar R, Tandon R, Pacsa AS, Younis Ol, Azizieh F. Sequential production of cytokines by dengue virus-infected human peripheral blood leukocyte cultures. J Med Virol. 1999:59(3):335-40.

56. Chunhakan S, Butthep P, Yoksan S, Tangnararatchakit K, Chuansumrit A. Vascular leakage in dengue hemorrhagic fever is associated with denque infected monocytes, monocyte activation/exhaustion, and cytokines production. Int J Vasc Med. 2015:2015:917143.

Ready to submit your research? Choose BMC and benefit from

- fast, convenient online submission

- thorough peer review by experienced researchers in your field

- rapid publication on acceptance

- support for research data, including large and complex data types

- gold Open Access which fosters wider collaboration and increased citations

- maximum visibility for your research: over $100 \mathrm{M}$ website views per year

At $\mathrm{BMC}$, research is always in progress.

Learn more biomedcentral.com/submissions 